\title{
Case Report: Management of Dead Intraocular Helminth Parasites in Asymptomatic Patients
}

\author{
Ranjit Sah, ${ }^{1 *}$ Anadi Khatri, ${ }^{2}$ Ranju Kharel, ${ }^{3}$ Hony Kc, ${ }^{2}$ Ali A. Rabaan, ${ }^{4}$ Ruchi Tiwari, ${ }^{5}$ Kuldeep Dhama, ${ }^{6}$ Yashpal Singh Malik, ${ }^{6}$ \\ Suzanne Donovan, ${ }^{7}$ Alfonso J. Rodriguez-Morales, ${ }^{8}$ Veronika Muigg, ${ }^{9,10}$ and Andreas Neumayr ${ }^{9,10}$ \\ ${ }^{1}$ Department of Microbiology, Tribhuvan University Institute of Medicine, Kathmandu, Nepal; ${ }^{2}$ Birat Eye Hospital, Biratnagar, Nepal; ${ }^{3}$ B.P. Koirala \\ Lions Centre of Ophthalmic Studies, Kathmandu, Nepal; ${ }^{4}$ Johns Hopkins Aramco Healthcare, Dhahran, Saudi Arabia; ${ }^{5}$ College of Veterinary \\ Sciences, UP Pandit Deen Dayal Upadhayay Pashu Chikitsa Vigyan Vishwavidyalay Evum Go-Anusandhan Sansthan (DUVASU), Mathura, India; \\ ${ }^{6}$ ICAR-Indian Veterinary Research Institute, Bareilly, India; ${ }^{7}$ Division of Infectious Diseases, Olive View-UCLA Medical Center, Los Angeles, CA; \\ ${ }^{8}$ Public Health and Infection Research Group, Faculty of Health Sciences, Universidad Tecnologica de Pereira, Pereira, Colombia; ${ }^{9}$ Department of \\ Medicine, Swiss Tropical and Public Health Institute, Basel, Switzerland; ${ }^{10}$ University of Basel, Basel, Switzerland
}

\begin{abstract}
We report four asymptomatic patients from Nepal with an incidental finding of a dead intraocular helminth parasite on ophthalmological routine examination. Because the patients were asymptomatic and the intraocular helminth parasites dead without noted pathology present, it was decided to abstain from surgical removal and pursue a watch-andwait strategy. The clinical follow-up of the four patients over two years was uneventful and showed no complications. We conclude that dead intraocular helminth parasites in asymptomatic patients without apparent pathology do not require surgical removal.
\end{abstract}

\section{CASE REPORTS}

Four asymptomatic patients diagnosed with dead intraocular helminth parasites on ophthalmological routine examination were referred to our tertiary care hospital in Kathmandu, Nepal, between February 2016 and March 2018. Table 1 summarizes the four patients' characteristics, and Figure 1 shows the photo documentation of the patients' intraocular helminth parasites.

In the absence of pathology requiring intervention (i.e., inflammatory or mechanical), it was decided to abstain from surgical resection of the helminth parasites and to pursue a watch-and-wait strategy with a close follow-up of the patients.

Because the helminth parasites in our four patients were not surgically removed, no definite species diagnosis can be provided. Nevertheless, the photo documentation was sent to the DPDx team at the Division of Parasitic Diseases and Malaria at the Centers for Disease Control and Prevention in Atlanta, GA and to the Swiss Diagnostic Reference Laboratory for Human Parasitic Diseases at the Swiss Tropical and Public Health Institute in Basel, Switzerland for review. Experts from both institutions concluded that according to the identifiable morphological features, the helminth parasites of cases 1, 2, and 3 are most likely plerocercoid larvae (spargana) of the genus Spirometra belonging to the class of Cestodes (tapeworms). The putative genus of the helminth parasite in case 4 was initially also determined as Spirometra but later revised to Angiostrongylus cantonensis, belonging to the class of nematodes (roundworms), following external peer review.

Because serological testing for tissue-invasive parasites is currently not available in Nepal and because the result would not have changed the clinical management of the patients, serological testing was omitted. The clinical follow-up of the four patients over 2 years was uneventful and showed no complications.

\footnotetext{
*Address correspondence to Ranjit Sah, Department of Microbiology, Tribhuvan University and Teaching Hospital (TUTH), Institute of Medicine, Maharagunj, 44600, Kathmandu, Nepal, E-mails: ranjitsah@iom.edu.np or ranjitsah57@gmail.com or Andreas Neumayr, Department of Medicine, Swiss Tropical and Public Health Institute, Socinstr. 57, 4051, Basel, Switzerland, E-mail: andreas. neumayr@swisstph.ch.
}

\section{DISCUSSION}

A broad range of anthroponotic and zoonotic helminth parasites are capable of coinfecting the human eye (Table 2). Although ocular affection is classically seen with some anthroponotic helminth parasites (e.g., subconjunctival migration of Loa loa macrofilariae or intraocular detection of microfilariae in onchocerciasis), invasion of the eye is not a mandatory part of any parasite's life cycle. Therefore, the finding of intraocular helminth parasites is a rare encounter and a result of parasites' aberrant tissue migration. Ocular pathology may be caused directly by tissue invasion and migration of parasite larvae or adults, or indirectly by toxic reactions and/or immune-mediated reactions. ${ }^{1}$

Three treatment options for intraocular helminth parasites are available: surgery, laser photocoagulation, and treatment with antiparasitic drugs. Which treatment option to choose primarily depends on the size and location of the parasite, the locally available resources, and the experience of the treating physician. Live intraocular helminth parasites are, if their size and location permit, surgically removed to prevent further damage. If surgical removal is not possible, because of the parasite's size and location, laser photocoagulation can be used to kill the parasite and prevent further migration-related damage. This method has proven to be very effective in treating "diffuse unilateral subacute neuroretinitis," a clinical entity caused by subretinal migration of various nematode larvae (including, e.g., Toxocara canis, Ancylostoma caninum, Strongyloides stercoralis, Ascaris lumbricoides, and Baylisascaris procyonis). ${ }^{2}$ If surgery and laser photocoagulation are not indicated, available, or possible, treatment with antiparasitic drugs presents an alternative. Adjunctive corticosteroid treatment is used in the presence of an inflammatory reaction or to avert treatmentinduced inflammatory reactions triggered by antigen liberation due to dying parasites. ${ }^{1}$

Although there is broad consensus on the indication to treat live intraocular helminth parasites by surgery, the indication for surgical removal of dead intraocular helminth parasites found on routine examinations in asymptomatic patients is less clear, especially if no concomitant pathology (inflammatory reaction, etc.) is present. 
TABLE 1

Characteristics of the four patients

\begin{tabular}{|c|c|c|c|c|c|c|}
\hline Patient number & Age (years) & Gender & Location of the dead helminth parasite & Vision & $\begin{array}{l}\text { Intraocular } \\
\text { pressure }\end{array}$ & Suspected parasite class/genus \\
\hline 1 & 44 & Male & $\begin{array}{l}\text { Behind the iris on the pupillary } \\
\text { border at } 5 \text { o'clock position }\end{array}$ & Unaffected & Normal & Cestode/Spirometra \\
\hline 2 & 45 & Female & $\begin{array}{l}\text { Anterior chamber: adherent to the } \\
\text { ciliary border of the iris at } 7 \\
\text { o'clock position }\end{array}$ & Unaffected & Normal & Cestode/Spirometra \\
\hline 3 & 59 & Male & $\begin{array}{l}\text { Anterior chamber: pupillary border } \\
\text { of the iris at } 3 \text { o'clock position }\end{array}$ & Unaffected & Normal & Cestode/Spirometra \\
\hline 4 & 47 & Female & $\begin{array}{l}\text { Anterior chamber: pupillary border } \\
\text { of the iris at } 4 \text { o'clock position }\end{array}$ & Unaffected & Normal & $\begin{array}{l}\text { Nematode/ } \\
\text { Angiostrongylus } \\
\text { cantonensis }\end{array}$ \\
\hline
\end{tabular}

Sparganosis. Spirometra species are globally distributed intestinal parasites of dogs, cats, and other mammals with a complex life cycle. Humans may get infected by 1) drinking water containing infected copepods (first intermediate host), 2) ingesting raw or undercooked flesh of a second intermediate host (e.g., frogs and snakes), or 3) applying flesh of a second intermediate host to wounds or mucous membranes. In the accidental human dead-end host, the larvae are capable of tissue invasive migration and may end up in any organ, including the eye. Spargana larvae may measure from millimeters up to $50 \mathrm{~cm}$ and remain viable up to several years (possibly decades). ${ }^{3}$ Mostly human infections present as subcutaneous nodules, and the diagnosis is only made after surgical resection. ${ }^{4}$ Drug treatment of sparganosis is

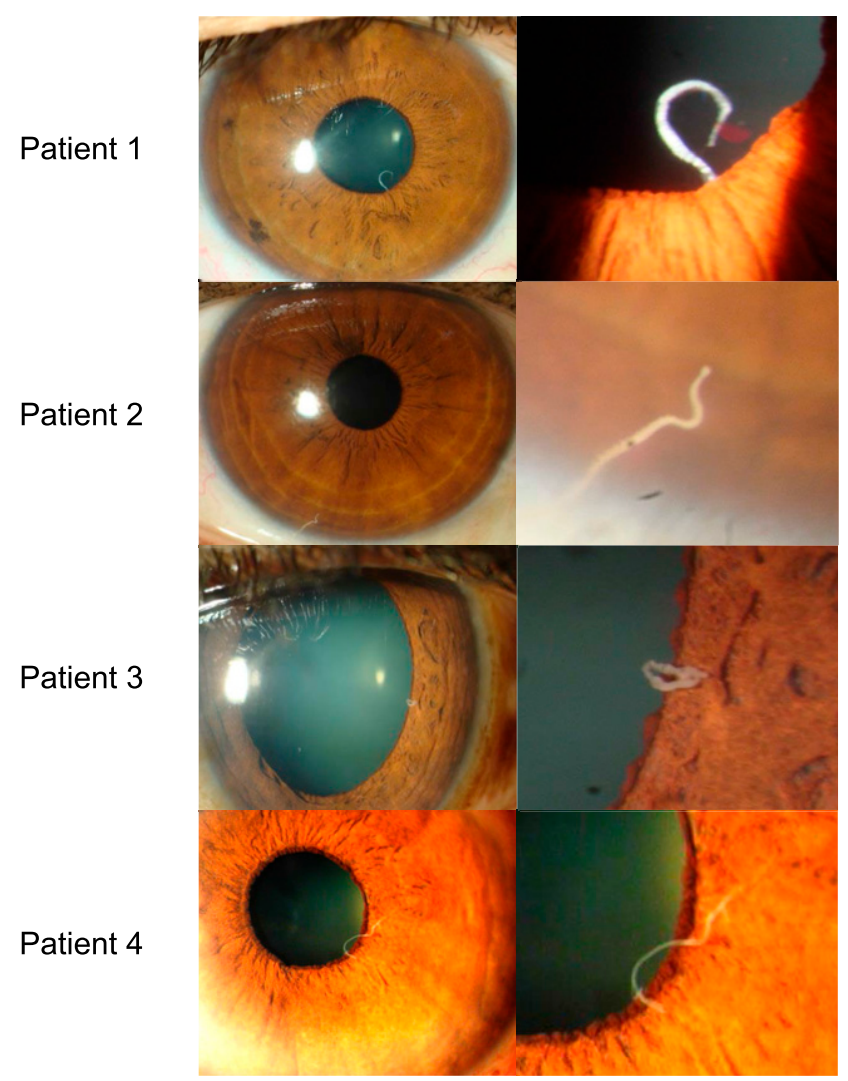

Figure 1. Photo documentation of the intraocular helminth parasites detected in the four patients. This figure appears in color at www.ajtmh.org. restricted to cases where surgical removal of larvae is impossible, for example, in cerebral sparganosis. In such cases, antiparasitic treatment with praziquantel has shown to be effective. ${ }^{5}$ Ocular sparganosis is a rare entity primarily reported from Southeast Asia in the past, when applying poultice made of frog or snake meat on open wounds or sore eyes was a common practice in traditional medicine. ${ }^{6}$ This practice, allowing direct tissue invasion by migratory spargana larvae, has fortunately become rare. However, spargana larvae may also migrate to and invade the eye in patients who are orally infected. ${ }^{7}$ The source of infection in our patients is unclear. The prevalence and natural hosts of Spirometra species is currently not well described in Nepal. Because our patients did not report suggestive food habits or high-risk traditional medicine practices, we suspect that they acquired their parasites via unfiltered water containing copepods harboring infective procercoid larvae. Reviewing the literature on ocular sparganosis, we found only case reports describing symptomatic infections with considerable pathology requiring surgical intervention.

Angiostrongyliasis. The rat lungworm (A. cantonensis) is a parasite whose main host is the rat in whose pulmonary arteries it lives. After hatching from their eggs in the rat's lung, larvae are passed in the feces and infect slugs or snails which serve the parasite as intermediate hosts. Humans get infected by ingesting 1) raw or undercooked snails or slugs, 2) paratenic hosts (crabs, frogs, and freshwater shrimps), or 3) vegetables contaminated with infective larvae. In the accidental human dead-end host, the parasite's larvae have a strong tropism for the central nervous system and are a worldwide leading cause of eosinophilic meningitis. Ocular invasion by an Angiostrongylus larva (2.6-12.6 mm in length) is reported in $1.1 \%$ of diagnosed angiostrongyliasis cases. ${ }^{8}$ Interestingly, we found no description of an ocular infection where more than one larva was found. Within the eye, the larva is primarily found in the vitreous cavity (39\%), subretinal space (33\%), and anterior chamber $(22 \%){ }^{9}$ Live larvae in the subretinal space are treated by laser photocoagulation, whereas live intracameral and intra-vitreal larvae are treated by laser photocoagulation followed by surgical removal. ${ }^{9}$ Reviewing the literature on ocular angiostrongyliasis, we found only case reports describing symptomatic infection with considerable pathology requiring intervention. The only case report we identified describing the finding of a dead intraocular Angiostrongylus larva was a 20-month-old child who had just received antiparasitic treatment for Angiostrongylus-related eosinophilic meningitis 
TABLE 2

Parasites reported to cause ocular human infection

\begin{tabular}{|c|c|c|c|c|}
\hline $\begin{array}{l}\text { Helminth pararasite } \\
\text { taxonomic group }\end{array}$ & Disease (name of the parasite) & $\begin{array}{l}\text { Parasite's characteristic } \\
\text { (natural definitive host) }\end{array}$ & $\begin{array}{l}\text { Tissue-invasive } \\
\text { parasite stage }\end{array}$ & Source of human infection \\
\hline \multirow[t]{12}{*}{$\begin{array}{l}\text { Nematodes } \\
\text { (roundworms) }\end{array}$} & $\begin{array}{l}\text { Ancylostomiasis (Ancylostoma } \\
\text { caninum) }\end{array}$ & Zoonosis (dogs) & Larvae & $\begin{array}{l}\text { Larvae present in soil contaminated } \\
\text { with dog feces penetrate the } \\
\text { intact skin }\end{array}$ \\
\hline & $\begin{array}{l}\text { Angiostrongyliasis (Angiostrongylus } \\
\text { cantonensis) }\end{array}$ & Zoonosis (rats) & Larva & $\begin{array}{l}\text { Ingestion of raw or undercooked } \\
\text { infected molluscs, snails, crabs, } \\
\text { frogs, or freshwater shrimps, or } \\
\text { vegetables containing infective } \\
\text { larvae }\end{array}$ \\
\hline & Ascariasis (Ascaris lumbricoides) & Anthroponosis & Larva & $\begin{array}{l}\text { Ingestion of eggs via food } \\
\text { contaminated with human feces }\end{array}$ \\
\hline & Baylisascariasis & Zoonosis (raccoons) & Larva & $\begin{array}{l}\text { Ingestion of eggs via soil } \\
\text { contaminated with raccoon feces }\end{array}$ \\
\hline & Dirofilariasis (Dirofilaria spp.) & Zoonosis (dogs and cats) & Adult worm & $\begin{array}{l}\text { Bite of bloodsucking mosquitoes } \\
\text { (Culex, Aedes, Ochlerotatus, and } \\
\text { Anopheles) }\end{array}$ \\
\hline & $\begin{array}{l}\text { Lymphatic filariasis (Wuchereria } \\
\text { bancrofti and Brugia spp.) }\end{array}$ & Anthroponosis & Adult worm & $\begin{array}{l}\text { Bite of bloodsucking mosquitoes } \\
\text { (Culex, Anopheles, Mansonia, and } \\
\text { Aedes) }\end{array}$ \\
\hline & Loiasis (Loa loa) & Anthroponosis & Adult worm & $\begin{array}{l}\text { Bite of bloodsucking deerfly } \\
\text { (Chrysops spp.) }\end{array}$ \\
\hline & $\begin{array}{l}\text { Onchocerciasis (Onchocerca } \\
\text { volvulus) }\end{array}$ & Anthroponosis & $\begin{array}{l}\text { Larva/adult } \\
\text { worm }\end{array}$ & $\begin{array}{l}\text { Bite of bloodsucking blackfly } \\
\text { (Simulum spp.) }\end{array}$ \\
\hline & $\begin{array}{l}\text { Gnathostomiasis (Gnathostoma } \\
\text { spp.) }\end{array}$ & Zoonosis (dogs, cats, a.o.) & Larva & $\begin{array}{l}\text { Ingestion of raw or undercooked } \\
\text { flesh of fish, snakes, snails, or } \\
\text { frogs containing infective larvae }\end{array}$ \\
\hline & $\begin{array}{l}\text { Strongyloidiasis (Strongyloides } \\
\text { stercoralis) }\end{array}$ & Anthroponosis & Larva & $\begin{array}{l}\text { Larvae present in soil contaminated } \\
\text { with human feces penetrate the } \\
\text { intact skin }\end{array}$ \\
\hline & Thelaziasis (Thelazia callipaeda) & Zoonosis (dogs and cats) & $\begin{array}{l}\text { Larva/adult } \\
\quad \text { worm }\end{array}$ & $\begin{array}{l}\text { Conjunctival deposition of infective } \\
\text { larvae via various secretophagus } \\
\text { flies }\end{array}$ \\
\hline & $\begin{array}{l}\text { Toxocariasis (Toxocara canis and } \\
\text { T. cati) }\end{array}$ & Zoonosis (dogs and cats) & Larva & $\begin{array}{l}\text { Ingestion of parasite eggs via fecally } \\
\text { contaminated soil, food, or water, } \\
\text { or ingestion of infective larvae in } \\
\text { raw or undercooked meat of } \\
\text { paratenic hosts }\end{array}$ \\
\hline \multirow[t]{5}{*}{ Trematodes (flukes) } & Alariasis (Alaria alata) & Zoonosis (frogs) & $\begin{array}{l}\text { Larva/adult } \\
\quad \text { worm }\end{array}$ & $\begin{array}{l}\text { Ingestion of undercooked frog flesh } \\
\text { containing mesocercariae } \\
\text { (infective larvae) }\end{array}$ \\
\hline & Fascioliasis (Fasciola hepatica) & Zoonosis (sheep) & $\begin{array}{l}\text { Larva/adult } \\
\quad \text { worm }\end{array}$ & $\begin{array}{l}\text { Ingestion of contaminated water or } \\
\text { water plants containing } \\
\text { metacercarial cysts (infective } \\
\text { larvae) }\end{array}$ \\
\hline & Paragonimiasis (Paragonimus spp.) & $\begin{array}{l}\text { Zoonosis (crabs, grayfish, } \\
\text { a.o.) }\end{array}$ & $\begin{array}{l}\text { Larva/adult } \\
\quad \text { worm }\end{array}$ & $\begin{array}{l}\text { Consumption of raw or under- } \\
\text { cooked crabs or crayfish } \\
\text { containing metacercariae } \\
\text { (infective larvae) }\end{array}$ \\
\hline & $\begin{array}{l}\text { Philophthalmosis (Philophthalmus } \\
\text { palpebrarum) }\end{array}$ & Zoonosis (birds) & $\begin{array}{l}\text { Larva/adult } \\
\quad \text { worm }\end{array}$ & $\begin{array}{l}\text { Contact with water or vegetables } \\
\text { contaminated with metacercariae } \\
\text { (infective larvae) }\end{array}$ \\
\hline & $\begin{array}{l}\text { Schistosomiasis (Schistosoma } \\
\text { spp.) }\end{array}$ & Anthroponosis & $\begin{array}{l}\text { Larva/adult } \\
\quad \text { worm }\end{array}$ & $\begin{array}{l}\text { Skin contact with fresh water } \\
\text { contaminated with cercariae } \\
\text { (infective larval stage) }\end{array}$ \\
\hline \multirow[t]{4}{*}{$\begin{array}{l}\text { Cestodes (tape } \\
\text { worms) }\end{array}$} & Coenuriasis (Taenia spp.) & Zoonosis (dogs, a.o.) & $\begin{array}{l}\text { Metacestode } \\
\quad \text { (cyst) }\end{array}$ & $\begin{array}{l}\text { Ingestion of parasite eggs via fecally } \\
\text { contaminated food or water }\end{array}$ \\
\hline & Cysticercosis (Taenia solium) & Anthroponosis & $\begin{array}{l}\text { Metacestode } \\
\quad \text { (cyst) }\end{array}$ & $\begin{array}{l}\text { Ingestion of parasite eggs via fecally } \\
\text { contaminated food or water }\end{array}$ \\
\hline & $\begin{array}{l}\text { Echinococcosis (Echinococcus } \\
\text { granulosus and E. multilocularis) }\end{array}$ & Zoonosis (dogs and foxes) & $\begin{array}{l}\text { Metacestode } \\
\quad \text { (cyst) }\end{array}$ & $\begin{array}{l}\text { Ingestion of parasite eggs via fecally } \\
\text { contaminated food or water }\end{array}$ \\
\hline & Sparganosis (Spirometra spp.) & $\begin{array}{l}\text { Zoonosis (various } \\
\text { mammals) }\end{array}$ & $\begin{array}{l}\text { Larva/adult } \\
\quad \text { worm }\end{array}$ & $\begin{array}{l}\text { Drinking water containing copepods } \\
\text { (first intermediate host) harboring } \\
\text { coraciidae (infective larvae), } \\
\text { ingesting raw or undercooked } \\
\text { flesh of a second intermediate } \\
\text { host (e.g., frogs and snakes) } \\
\text { harboring infective larvae, or } \\
\text { applying flesh of a second } \\
\text { intermediate host to wounds or } \\
\text { mucous membranes }\end{array}$ \\
\hline
\end{tabular}


when additionally unilateral retinal pathologies and a dead larva in the vitreous cavity were discovered. ${ }^{10}$

Why in our four cases no local signs of concomitant or past inflammation was present remains unclear. Considering that tissue invasive parasites will only be recognized and diagnosed once they have reached a detectable size (macroscopically or by imaging methods) and/or cause clinical apparent pathology, we speculate that infections with still small and prematurely dying parasites are more likely to remain asymptomatic or oligosymptomatic and thus undiagnosed. This assumption is supported by the small size of the plerozercoid larvae in our three cases when compared with the reported size of procercoid larvae resected from the periocular soft tissue. ${ }^{11-13}$ In addition, once inside the eye, parasites find themselves in a relatively protected site from the host immune response. ${ }^{14}$

A major limitation of our study is that we can neither provide definitive proof of the diagnosis nor a species identification. A positive serological test could have supported the morphological diagnosis. However, serologies for tissue-invasive parasites are currently not available in Nepal, and in our experience, a negative serological test would not have refuted the diagnosis because following treatment or the natural death of a parasite seroreversion is more the rule than the exeption.

Our report is the first case series examining the role of observation, without intervention, in asymptomatic patients with reported dead intraocular helminth larvae not causing obvious pathology. We conclude that in asymptomatic patients, dead intraocular helminth larvae not causing apparent pathology do not require surgical removal and patients may be followed up under a watch-and-wait strategy.

Received March 27, 2020. Accepted for publication April 23, 2020.

Published online June 1, 2020.

Acknowledgments: We want to thank the DPDx team at the Division of Parasitic Diseases and Malaria at the Centers for Disease Control and Prevention in Atlanta, GA; the Team of the Swiss Diagnostic Reference Laboratory for Human Parasitic Diseases at the Swiss Tropical and Public Health Institute in Basel, Switzerland; and the peer reviewers of this article for their critical review of the photographic material.

Authors' addresses: Ranjit Sah, Department of Microbiology, Tribhuvan University Institute of Medicine, Kathmandu, Nepal, E-mails: ranjitsah@iom.edu.np or ranjitsah57@gmail.com. Anadi Khatri and Hony Kc, Birat Eye Hospital, Biratnagar, Nepal, E-mails: anadikc@ gmail.com and honykc@gmail.com. Ranju Kharel, B.P. Koirala Lions Centre of Ophthalmic Studies, Kathmandu, Nepal, E-mail: helloranju50@gmail.com. Ali A. Rabaan, Johns Hopkins Aramco Healthcare, Dhahran, Saudi Arabia, E-mail: arabaan@gmail.com. Ruchi Tiwari, College of Veterinary Sciences, UP Pandit Deen Dayal
Upadhayay Pashu Chikitsa Vigyan Vishwavidyalay Evum GoAnusandhan Sansthan (DUVASU), Mathura, India, E-mail: ruchi.vet@ gmail.com. Kuldeep Dhama and Yashpal Singh Malik, ICAR-Indian Veterinary Research Institute, Bareilly, India, E-mails: kdhama@ rediffmail.com and malikyps@gmail.com. Suzanne Donovan, Division of Infectious Diseases, Olive View-UCLA Medical Center, E-mail: sdonovanmd@gmail.com. Alfonso J. Rodriguez-Morales, Public Health and Infection Research Group, Faculty of Health Sciences, Universidad Tecnologica de Pereira, Pereira, Colombia, E-mail: ajrodriguezmmd@gmail.com. Veronika Muigg and Andreas Neumayr, Department of Medicine, Swiss Tropical and Public Health Institute, Basel, Switzerland, E-mails: veronika.muigg@swisstph.ch and andreas.neumayr@swisstph.ch.

\section{REFERENCES}

1. Padhi TR, Das S, Sharma S, Rath S, Tripathy D, Panda KG, Basu S, Besirli CG, 2017. Ocular parasitoses: a comprehensive review. Surv Ophthalmol 62: 161-189.

2. Natesh S, Harsha K, Nair U, Nair K, 2010. Subretinal worm and repeat laser photocoagulation. Middle East Afr J Ophthalmol 17: 183-185.

3. Neumayr A, ed. 2018. Sparganosis Antiparasitic Treatment Recommendations - A Practical Guide to Clinical Parasitology. 2nd edition. Hamburg, Germany: tredition $\mathrm{GmbH}$.

4. Muigg V, Ruf MT, Schwarzkopf S, Huang S, Denisjuk N, Stürmann A, Ritzler M, Wampfler R, Poppert S, Neumayr A, 2019. Case report: human subcutaneous sparganosis in a Thai migrant. $A m$ J Trop Med Hyg 101: 1170-1173.

5. Hong D, Xie H, Wan H, An N, Xu C, Zhang J, 2018. Efficacy comparison between long-term high-dose praziquantel and surgical therapy for cerebral sparganosis: a multicenter retrospective cohort study. PLoS Negl Trop Dis 12: e0006918.

6. Xie X, Hu J, Sun G, Ding B, Feng L, 2018. Orbital sparganosis in an 8-year boy: a case report. BMC Ophthalmol 18: 13.

7. Sen DK, Muller R, Gupta VP, Chilana JS, 1989. Cestode larva (sparganum) in the anterior chamber of the eye. Trop Geogr Med 41: 270-273.

8. Sawanyawisuth K, Kitthaweesin K, Limpawattana P, Intapan PM, Tiamkao S, Jitpimolmard S, Chotmongkol V, 2007. Intraocular angiostrongyliasis: clinical findings, treatments and outcomes. Trans R Soc Trop Med Hyg 101: 497-501.

9. Sinawat S, Trisakul T, Choi S, Morley M, Sinawat S, Yospaiboon Y, 2019. Ocular angiostrongyliasis in Thailand: a retrospective analysis over two decades. Clin Ophthalmol 13: 1027-1031.

10. Andrade GC, Dias JRO, Maia A, Kanecadan LA, Moraes NSB, Belfort Junior R, Lasiste JME, Burnier MN, 2018. Intravitreal Angiostrongylus cantonensis: first case report in South America. Arq Bras Oftalmol 81: 63-65.

11. Nath R, Gogoi RN, 2015. Ocular sparganosis from Assam. Trop Parasitol 5: 64-67.

12. Ho TH, Lin MC, Yu WW, Lai PH, Sheu SJ, Bee YS, 2013. Ocular sparganosis mimicking an orbital idiopathic inflammatory syndrome. Orbit 32: 395-398.

13. Botterel F, Bourée $P, 2003$. Ocular sparganosis: a case report. J Travel Med 10: 245-246.

14. Zhou R, Caspi RR, 2010. Ocular immune privilege. F1000 Biol Rep 2: 3. 